\title{
高分子材料の耐キャビテーション壊食性*
}

\author{
服部修 次*1, 伊藤隆 基*1, 森 啓之*2
}

\section{Cavitation Erosion Resistance of High Polymer Materials}

\author{
Shuji HATTORI, Takamoto ITOH ${ }^{* 3}$ and Hiroyuki MORI \\ ${ }^{* 3}$ Department of Mechanical Engineering, University of Fukui, \\ 3-9-1 Bunkyo, Fukui-shi, Fukui, 910-8507 Japan
}

\begin{abstract}
Cavitation erosion and fatigue tests were cariied out for high polymer materials; epoxy resin, polypropylene, high-density polyethylene and polyamide 66 , and the relationship between cavitation erosion resistances and mechanical properties was examined. Resistance of cavitation erosion for high polymer materials is ranged between half and 30 times in comparison with that for carbon steels. Cavitation erosion for high polymer materials is caused by fatigue as well as metals. As high polymer materials have relatively small acoustic impedance, impact loads applied by collapse of bubbles becomes so small. Therefore, the resistance and incubation period of cavitation erosion for high polymer materials can be evaluated by strain energy in fatigue by taking account of impact energy due to collapse of bubbles.
\end{abstract}

Key Words: Cavitation Erosion, Fatigue, High Polymer Materials, Damage, Bubble, Fluid Machinery

\section{1. 緒 言}

キャビテーション環境下で生じる機器構造部材の 壊食を軽減もしくは補修する方法として，金属めっ きや肉盛り材料などの金属系の表面被覆の他に, 比 較的施工の容易な高分子材料がよく使用されている. 高分子材料の耐キャビテーション壊食性については ナイロン(1)やポリエチレ゙ン(2)が優れているとされて いるが，壊食特性やその定量的評価については明ら かにされていない，而壊食性と機械的性質の関係に ついては破断伸び(3)やショア硬さ(4)で整理すること が試みられているが，かならずしも良い相関がみら れない.

本研究では，4種類の高分子材料を対象にキャビ テーション壊食試験を行い, 壊食量の測定および壊 食面の観察から壊食機構を明らかにした．また，キ ヤビテーション気泡崩壊に伴う衝撃力の測定や疲労 試験結果から，金属材料の結果と比較検討して，高

* 原稿受付 2004 年 8 月 9 日.

*1 正員, 福井大学工学部 (- 910-8507 福井市文京 3-9-1).

*2 正員, (株) 神戸製鋼所(严651-2271 神戸市西区高塚台 1-55).

E-mail : itoh@mech.fukui-u.ac.jp
分子材料の耐壊食性を定量的に評価した.

\section{2. 試験片および試験方法}

2.1 供試材料試験に用いた高分子材料は, 熱硬化性樹脂のエポキシ樹脂（以下，EP）と熱可 塑性樹脂のポリプロピレン（以下，PP），高密度 ポリエチレン（以下, HDPE) およびポリアミド 66 (以下，PA66）の4種類である.また，比較材 には純アルミニウムA1050（以下， $\mathrm{Al}$ ) および一般 構造用圧延鋼SS400（以下，SS）を用いた。表1に 各供試材料の物理的および機械的性質を示す.

2.2 キャビテーション壊食試験＼cjkstart壊食試験は磁 歪振動装置を用いて静置試験法で行った(5). 振動子 の増幅ホーンの先端に耐壊食性に優れている $\phi 16 \mathrm{~mm}$ のSUS304ステンレス鋼製のディスクを取 付けた. 試験片は, $25 \mathrm{~mm} \times 25 \mathrm{~mm}$, 厚さ $3 \mathrm{~mm}$ の平 板で，ディスク先端から $1 \mathrm{~mm}$ を隔てて固定し，キ ヤビテーションに曝した。振動子の共振周波数は $19.5 \mathrm{kHz}$ ，ディスク端面の全変位振幅は $50 \mu \mathrm{m}$ 一定 とした. 試験液はイオン交換水を用い, 液温は電子 恒温装置に循環させて $25 \pm 1^{\circ} \mathrm{C} に$ 保持した. 
Table 1 Physical properties (at $25^{\circ} \mathrm{C}$ ) of the test materials and test liquid.

\begin{tabular}{|c|c|c|c|c|c|c|c|c|c|}
\hline \multicolumn{3}{|c|}{ Materials } & \multirow{2}{*}{$\begin{array}{c}\begin{array}{c}\text { Density } \\
\rho \\
\mathrm{kg} / \mathrm{m}^{3}\end{array} \\
1.22 \times 10^{3}\end{array}$} & \multirow{2}{*}{ 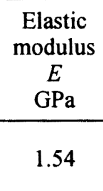 } & \multirow{2}{*}{$\begin{array}{c}\begin{array}{c}\text { Acoustic } \\
\text { impedance } \\
Z \\
\mathrm{Ns} / \mathrm{m}^{3}\end{array} \\
1.37 \times 10^{6}\end{array}$} & \multirow{2}{*}{$\begin{array}{c}\text { Vickers } \\
\text { hardness } \\
H V\end{array}$} & \multirow{2}{*}{$\begin{array}{c}\text { Glass } \\
\text { temp. } \\
T_{g} \\
{ }^{\circ} \mathrm{C} \\
140\end{array}$} & \multirow{2}{*}{$\begin{array}{c}\text { Melting } \\
\text { point } \\
T_{m} \\
{ }^{\circ} \mathrm{C} \\
-\end{array}$} & \multirow{2}{*}{$\begin{array}{c}\text { Thermal } \\
\text { conductivity } \\
q \\
\mathrm{~W} /\left(\mathrm{m} \cdot{ }^{\circ} \mathrm{C}\right)\end{array}$} \\
\hline $\begin{array}{l}\text { Thermosetting } \\
\text { resin }\end{array}$ & Epoxy resin & EP & & & & & & & \\
\hline \multirow{3}{*}{$\begin{array}{l}\text { Thermoplastic } \\
\text { resin }\end{array}$} & Polypropylene & PP & $0.91 \times 10^{3}$ & 1.17 & $1.03 \times 10^{6}$ & 8 & -10 & 176 & 0.18 \\
\hline & $\begin{array}{l}\text { High-density } \\
\text { polyethylene }\end{array}$ & HDPE & $0.95 \times 10^{3}$ & 0.87 & $0.91 \times 10^{6}$ & 4 & -120 & 137 & 0.49 \\
\hline & $\begin{array}{l}\text { Polyamide } \\
\quad 66\end{array}$ & PA66 & $1.14 \times 10^{3}$ & 0.60 & $0.83 \times 10^{6}$ & 1 & 47 & 267 & 0.25 \\
\hline \multirow{2}{*}{ Metal } & $\mathrm{A} 1050$ & $\mathrm{Al}$ & $2.71 \times 10^{3}$ & 61.7 & $12.9 \times 10^{6}$ & 35 & - & 660 & 221.9 \\
\hline & SS400 & SS & $7.87 \times 10^{3}$ & 206 & $40.3 \times 10^{6}$ & 113 & - & 1480 & 55.8 \\
\hline Liquid & \multicolumn{2}{|c|}{ Ion ex. water } & $1.00 \times 10^{3}$ & 2.22 & $1.49 \times 10^{6}$ & - & - & 0 & 0.58 \\
\hline
\end{tabular}

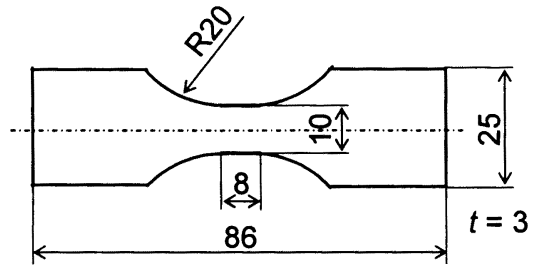

Fig.1 Shape and dimensions of specimen employed in tension and fatigue tests (mm).

試験片は所定時間毎に取り外し，イオン交換水で 超音波洗浄した後, 真空ポンプで10分間脱水した. 壊食量は，質量减少量を直示天秤（感度 $0.01 \mathrm{mg}$ ） で測定した.

\section{3 引張試験および疲労試験 引張試験およ} び疲労試験に用いた試験片は, 平板から図1に示す 形状に加工した. 高分子材料は吸水率が高いので, 試験条件を揃えるために，すべての試験で試験片を $25^{\circ} \mathrm{C}$ のイン交換水中に 1 日浸漬した後, 試験を開 始した. 引張試験はストローク制御で, その速度は $1 \mathrm{~mm} / \mathrm{min}$ とした. 疲労試験は, 常温大気中の下で, 電気油圧サーボ試験機を用いて, 繰返し速度を $5 \mathrm{~Hz}$, 平均応力零の両振引張/圧縮荷重を負荷して行った.

\section{3. 実験結果および考察}

3.1 キャビテーション壊食試験結果図2に高 分子材料の体積减少量曲線を示す.ただし, 繸軸の 体積減少量 $V_{L}$ は, 質量减少量を材料の密度 $\rho$ で除し

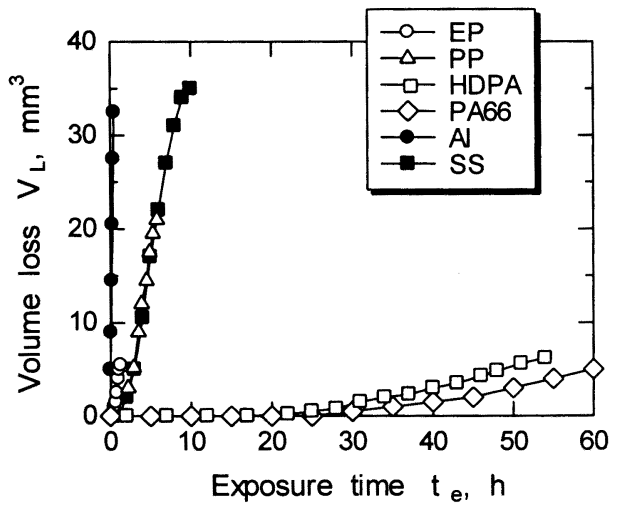

Fig.2 Volume loss curves.

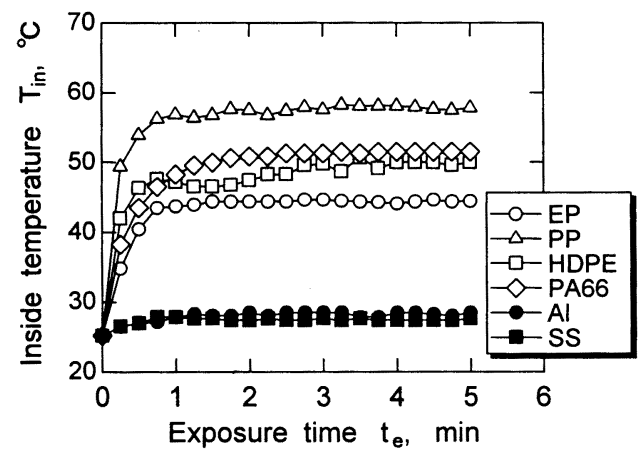

Fig.3 Variation of temperature in specimen by cavitation erosion test as a function of exposure time. 
て表した。 また, 図中には比較材料のAlおよびSS の結果も併せて示す. いずれの材料試験でも, 従来 から報告されている結果(4) と同様に，壊食量が僅か である一定の潜伏期間を経た後, 壊食量が急激に増 加する最大速度期に至る過程が見られる．直線の傾 きから最大速度期の体積減少速度を求めると, PA66はEPの約 $1 / 60$ で最も良い耐壊食性を示す。ま た, SSの体積减少速度と比較してもPA66は約 $1 / 30$ で，一般の鉄鋼材料よりも硬さが著しく低いにもか かわらず，而壊食性は非常に優れている．HDPEに ついても，PA66に次いで良い耐壊食性を示す.

試験面から哚さ $0.7 \mathrm{~mm}$ の位置で, 壊食試験時の 内部温度 $\left(T_{i n}\right)$ を熱電対により測定した. 図3は試 験時間の增加に伴う $T_{\text {in }}$ の変化を示す.すべての高 分子材料の $T_{\text {in }}$ は試験開始後 $1 \mathrm{~min}$ までに急激に増加 し，それ以降の試験時間ではほぼ一定となる。しか し, A1およびSSの $T_{\text {in }}$ は, 試験開始直後に若干の増

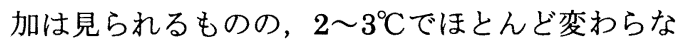
い. 高分子材料と金属材料の違いによる $T_{\text {in }}$ の増加 量の差は，キャビテーション気泡崩壊圧が繰返し作 用すると試験片内部で発熱し，高分子材料では熱伝 導率が小さいために蓄熱しやすいためであると考え られる.

高分子材料は温度によって機械的性質が大きく変 化するので, 種々の温度で引張試験を行なって縦弾 性係数 $E$ および引張強さ $\sigma_{B}$ を求めた. 図 4 に示すよ うにいずれの高分子材料でも試験温度の増加に伴い $E$ および $\sigma_{B}$ は共に低下するが，その低下の傾向は材 料に依存する，また，EPについてはその低下割合 が他の材料に比べて小さい.

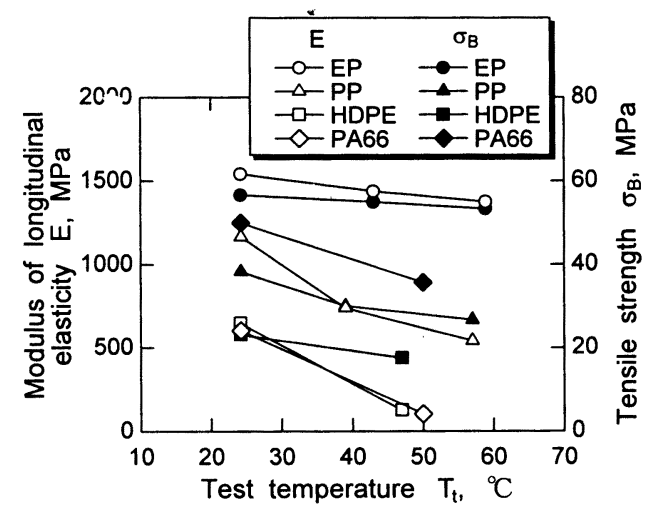

Fig.4 Variations of elastic modulus and tensile strength as a function of test temperature.

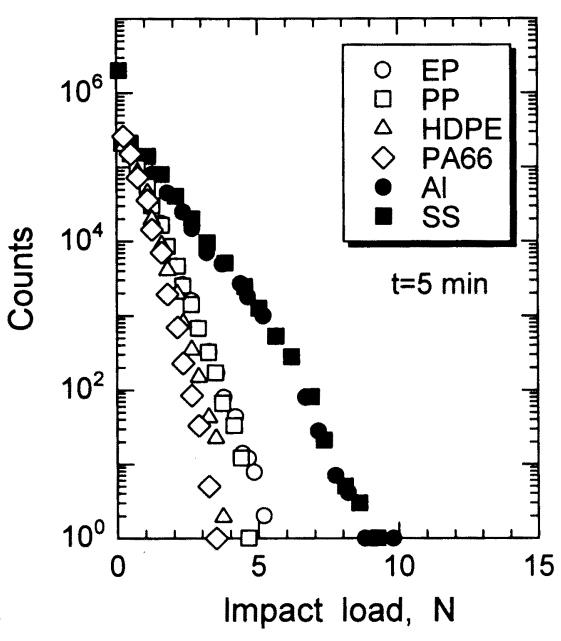

Fig.5 Distribution of impact loads produced by capitation bubble collapse.

3.2 気泡崩壊圧の測定 高分子材料の表面に 作用する気泡崩壊圧を, 著者らが開発した圧力セン サと計測システム(6)を用いて測定した。供試材料を 一辺が $3 \mathrm{~mm}$ の立方体に機械加工し，これを直径 $3 \mathrm{~mm}$ の受圧棒の上面に瞬間接着剂で接着して, 磁 歪振動装置で生じる気泡崩壊時に発生する衝撃力を 計測した．図5は5minにわたって測定した衝撃力の 発生頻度分布を示したものである. どの材料でも， 衝撃力の大きさが大きくなるにつれて発生個数は加 速度的に減少する. また, 高分子材料での最大衝撃 力や発生個数はAlやSSに比べて小さいことがわか る.

キャビテーション気泡崩壊圧が水滴や水流の衝突 と同様な機構で作用していると考えると，材料表面 に発生する圧力 $p$ は次式で与えられる(7).

$$
\begin{aligned}
& p=Z_{V} \\
& Z=\left(\frac{1}{Z_{1}}+\frac{1}{Z_{2}}\right)^{-1}
\end{aligned}
$$

$Z_{1}$ : 液体の音響インピーダンス $\left(=\sqrt{E_{1} \rho_{1}}=c_{1} \rho_{1}\right)$

$E_{1}$ : 液体の弾性係数, $\rho_{1}$ : 密度, $c_{1}$ : 音速 $Z_{2}$ : 固体の音響インピーダンス $\left(=\sqrt{E_{2} \rho_{2}}=c_{2} \rho_{2}\right)$

$E_{2}$ : 固体の縦弾性係数, $\rho_{2}$ : 密度, $c_{2}$ : 音速 $v:$ 水流の衝突速度

すなわち，水中での気泡崩壊による衝突速度 $v か ゙ 一$ 定と仮定すると，衝撃圧 $p$ は $Z\left(=\left(1 / Z_{1}+1 / Z_{2}\right)^{-1}\right)$ に比例する. 
図6は $Z$ と図 5 で得られた各材料の最大衝撃力の関 係を示したものである. なお，それぞれの材料はキ ヤビテーションが作用したとき図3のように温度上 昇するので, 縦弾性係数は温度上昇を加味して図 4 から求めたものを用いた. 最大衝撃力と $Z$ は一本の 直線で表され, 得られた衝撃力の分布が妥当である ことを示している. また, 液体の音響インピーダン スは試験液にイオン交換水を用いているので各試験 で同じである $\left(Z_{1}=1.49 \times 10^{6} \mathrm{Ns} / \mathrm{m}^{3}\right)$ ．したがって， 材料表面に作用する気泡崩壊に伴うエネルギーは試 験材料の音響インピーダンスの大きさによってのみ 決定される。

図7に音響インピーダンスと図5の結果から得ら れる衝撃力 $F_{i}$ の頻度分布から求めた衝撃エネルギー 相当量 $\Sigma F_{i}^{2}(5)$,(7)の関係を示す. なお, $\Sigma F_{i}^{2}$ は最大速

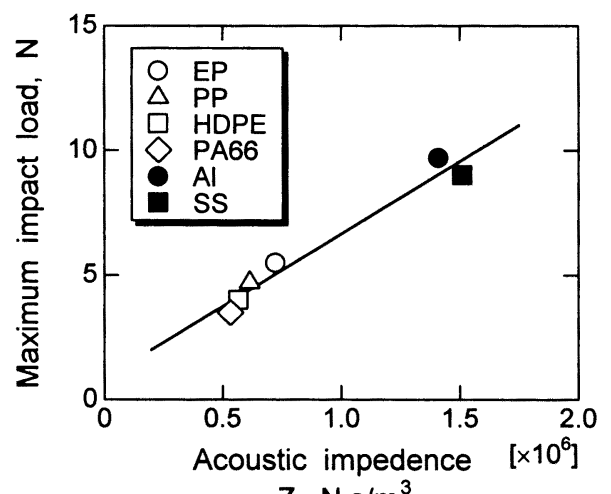

Z, $N \cdot s / m^{3}$

Fig.6 Relationship between maximum impact load and acoustic impedance.

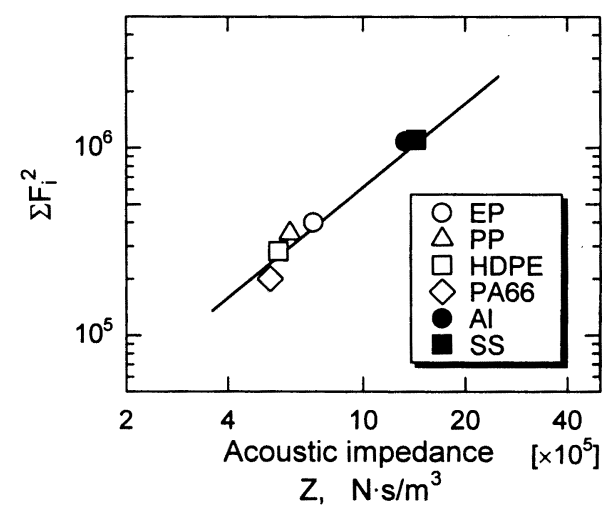

Fig.7 Relationship between $\Sigma F_{i}^{2}$ and acoustic impedance of material.
度期で単位体積壊食させるのに要する衝撃エネルギ 一である. $\mathrm{Al} \mathrm{SS}$ 金属材料のように音響インピ 一ダンスの大きな材料では大きな衝撃エネルギーが 作用するが，高分子材料のように音響インピーダン スの小さい材料では材料表面に作用する衝撃エネル ギーは小さくなることがわかる. また, 衝撃エネル ギーと壊食量は比例関係にあることを報告(8)してい るので, このように衝撃エネルギーが小さくなるこ とにも起因して, 高分子材料の壊食量が小さくなる と考えられる.

高分子材料の耐壊食性を衝撃エネルギーを用いて 定量的に評価した. ただし, 圧カセンサの受圧面積 と壊食面積は異なるので, 図7の衝撃エネルギーを 壊食面積当たりに作用するエネルギーに換算した。

また，換算した衝撃エネルギーを体積减少速度で除 して, 単位体積壊食させるのに要する衝撃エネルギ 一を求めた.この值は材料に与えられる衝撃エネル ギーを考慮した各材料の壊食抵抗を示す. 壊食抵抗 は破壊までに要するひずみエネルギーUltimate Resilience $\left(=\sigma_{b}^{2} / 2 E\right)$ と良い相関関係があること が報告(9)されているので, 本研究でも同样に図4の 引張試験結果から $\sigma_{B}^{2} / 2 E$ を求め, 壊食抵抗との関係 を示した結果を図8に示す，なお，図中にはAlおよ びSSの結果(10)も併せて示している. 高分子材料の 結果では, 金属材料の結果に比べてデータのばらつ きが大きく，このような静的な強度パラメータでは うまく評価できないことがわかる。

3.3 高分子材料の壊食機構 EPおよびPA66 の壊食面の様子を, 走查型電子顕微鏡（SEM）を 用いて観察した結果を，それぞれ図9および図10に 示す．図(a)および図(b)は同一籄所である．図9(a)

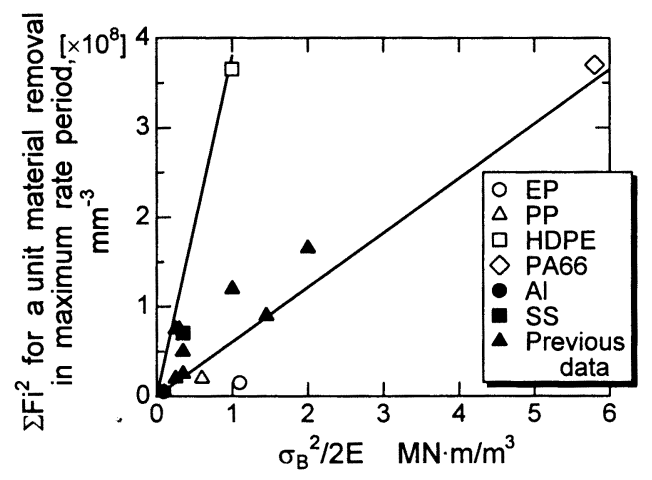

Fig.8 Relationship between $\sigma_{B}{ }^{2} / 2 E$ and $\Sigma F_{i}^{2}$ for a unit material removal. 


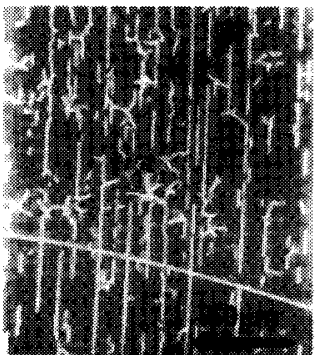

(a) $t_{e}=25 \mathrm{~min}$

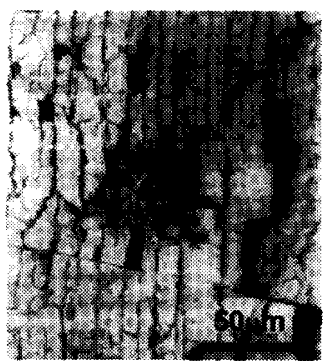

(b) $t_{e}=55 \mathrm{~min}$
Fig.9 Micrograph of eroded surface for EP.

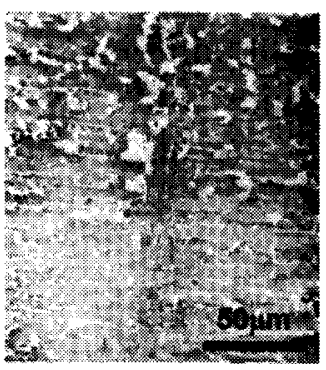

(a) $t_{e}=1 \mathrm{~h}$

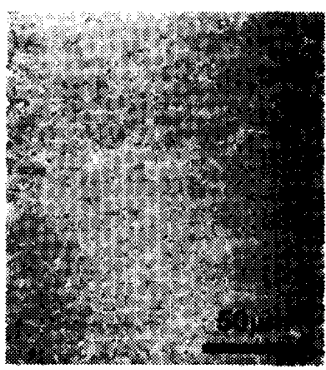

(b) $t_{e}=10 \mathrm{~h}$
Fig.10 Micrograph of eroded surface at for PA66.

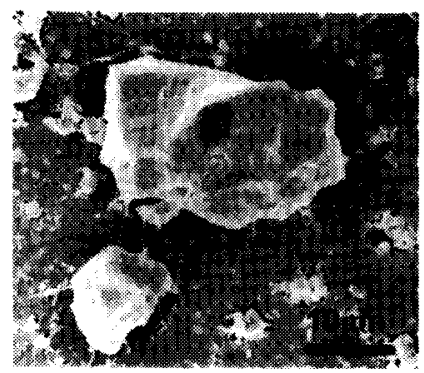

Fig.11 Micrograph of dropped particles at $t_{e}$ $=70 \mathrm{~min}$ for $\mathrm{EP}$.

はEPの壊食試験時間 $t_{e}=25 \mathrm{~min}$ の結果で, 体積减少 量曲線では潜伏期に当る．研磨傷に沿ってひび割れ が一方向に発生し，所々で枝分かれして成長してい る様子も見られる。また，初期の壊食痕も観察でき る. 体積减少速度がほぼ一定となる $t_{e}=55 \mathrm{~min}$ の結 果（図9(b)）では，全面で剥離が生じ，壊食痕も大 きくなっている，図示は省略するが，ひび割れには クレイズが確認された。すなわち，EPの壊食の進 展過程は，材料表面の研摩痕に沿ってクレイズが発 生し，それに沿ってひび割れが発生・成長して粒子
の脱落が生じる.

図10(a)は, 壊食抵抗の最も大きいPA66の $t_{e}=1 \mathrm{~h}$ の壊食面で，表面は紼維状にむしり取られた延性的 な破壊の様相を呈しており，ひび割れも観察される。 しかし，表面の脱落はほとんどない，図10(b)のte $=10 \mathrm{~h}$ の結果では，壊食面はうろこ状となりひび割 れが多数観察される.

各高分子材料の試験途中で脱落粉が混在した試験 液から，0.1 $\mu \mathrm{m}$ の最大透過径をもつ多孔質高分子つ イルタでろ過して採取した脱落粉をSEMで観察し た. 壊食の初期では $2 \sim 4 \mu \mathrm{m}$ 程度の小さい脱落粉し か観察されないが，最大速度期になると，どの高分 子材料の結果でも図11（一例としてEPの結果を図

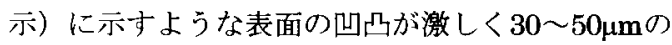
大きなものも観察された。

3.1節で述べたように体積减少量曲線に潜伏期が 存在すること，壊食面や脱落粉に貝殼状の模様やき 裂が多数観察されること，さらに定常期では大きな 壊食粉が形成されることから，金属材料と同様に高 分子材料の壊食も疲労破壊的に進行するものと考え られる。

3.4 疲労試験結果図12に疲労試験で得られ た忘力振幅 $\sigma_{a}$ と破断繰返し数 $N_{f}$ の)関倸 $(\mathrm{S}-\mathrm{N}$ 曲 線）を示す． EP，PPおよびHDPEでは，S-N曲線 の勾配は緩やかであるが，PA66ではその勾配は急 激である. 高分子材料では破断繰返し数が $10^{6} \sim 10^{7}$ 回でも横軸と水平にならず，徐々に低下している. そこで, 各材料について, $N_{f}=10^{7}$ の応力振幅を疲 労強度 $\sigma_{w}$ とした。 $\sigma_{R}=10 \mathrm{MPa} \sigma$ 試験の繰返し数の 増加に伴う試験片表面温度の変化を測定したところ, どの材料でも繰返し数が $10^{4}$ 回付近までに温度が急

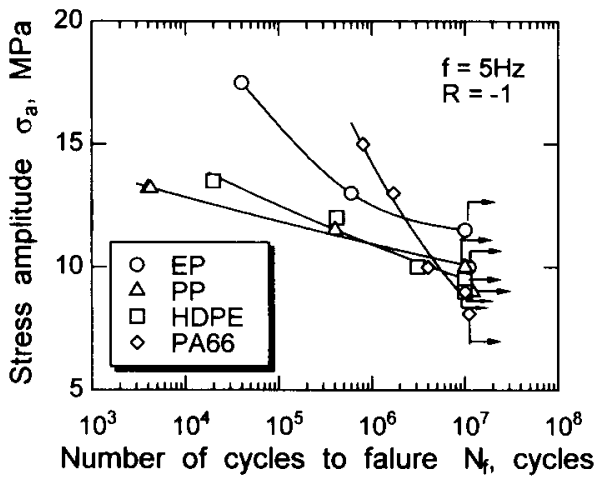

Fig.12 Stress-strain curve. 


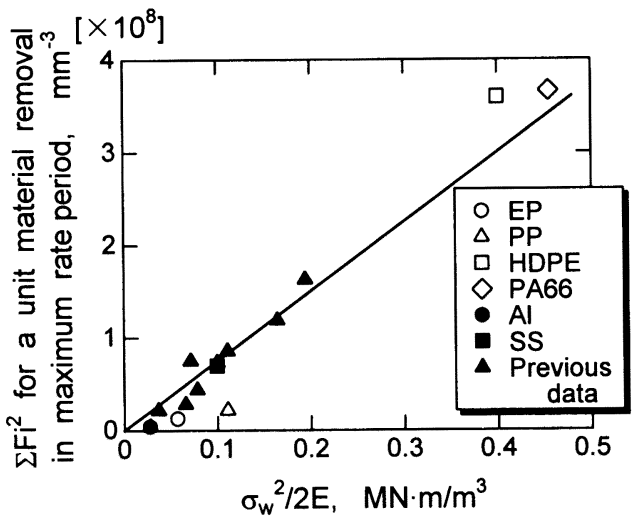

Fig.13 Relationship between $\sigma_{w}^{2} / 2 E$ and $\Sigma F_{i}^{2}$ for a unit material removal.

激に上昇して，それ以降ではそれほど大きな変化は ない, また, 試験片温度の上昇量は $10 \sim 40^{\circ} \mathrm{C}$ 程度 で, 図3の壊食試験時における温度の上昇量とほぼ 一致した.

\section{5 壊食抵抗と疲労強度の関係高分子材料}

の壊食抵抗と $\sigma_{w}$ との関係を定量的に評価した. 図 12 で得られた $\sigma_{w}$ を用いて疲労破壊に要するひずみ エネルギー相当量 $\sigma_{w}^{2} / 2 E$ を算出し，図8に示した定 常期に単位体積壊食させるのに要する衝撃エネルギ 一を $\sigma_{w}{ }^{2} / 2 E て ゙$ 整理し直した結果を図13に示す. 高分 子材料は金属材料を含めて原点を通る一本の直線で 示すことができ，壊食抵抗は材料表面に作用する衝 撃エネルギーを考慮すれば疲労強度を用いてうまく 整理できることがわかる.

\section{4. 結言}

本研究では, 高分子材料のキャビテーション壞食 試験による壊食の評価, 疲労試験および気泡崩壊圧 測定を行い，材料の耐壊食性と機械的性質を対応さ せた. その結果, 以下の結論を得た.

（1）鉄鋼材料のSS400と比べると，高分子材料では PA66のように壊食抵抗が約30倍のものから， $\mathrm{EP}$ のように $1 / 2$ 程度のものまであり, 耐キャビ テーション壊食性は材料によって大きく異なる.
（2）高分子材料はキャビテーション環境下において 蓄熱しやすいことから，キャビテーション壊食 性の評価には, 温度上昇による材料の機械的性 質の変化を考慮する必要がある.

（3）高分子材料のキャビテーション壊食は, 金属材 料と同様に疲労破壊的な機構で進展する.

（4）高分子材料は音響インピーダンスが非常に小さ いために，同じインテンシティーの下でも材料 に作用する衝撃力が小さくなる.

（5）したがって，気泡崩壊に伴う衝撃エネルギーを 考慮すれば，壊食抵抗は疲労強度から得られる ひずみエネルギーで定量的に評価できる.

\section{参考文献}

(1) Lichtman, J. and Kallas, D., Erosion resistance of coatings methods for evaluating erosion (cavitation) damage, Materials Protection, 4-40 (1967), 40-45.

(2) Topchiashvili, M.I., Andrianov, K.A. and Shalnev, K.K., Use of polymeric materials for protection against cavitation erosion, IAHR/AIRH Symposium 1970, Stockholm, (1970), 1-7.

(3) Lichtman, J.Z., Kallas, D.H., Chatten, C.K. and Cochran, C.E.P., Cavitation erosion of structural materials and coatings, Corrosion, 17 (1961), 119-127.

(4) Heathcock, C.J., Protheroe, B.E. and Heathcock, B.A., The influence of microstructure on the cavitation erosion of materials, Proc. $5^{\text {th }}$ Int. Conf. on Erosion by Liquid and Solid Impact, (1979), 63-1.

（5）服部修次, 田中雄,キャビテーション壊食に及ぼす液 体の空気含有度と蒸気圧の影響, 機論, 68-675, B (2003), 3080-3086.

(6) Okada, T., Iwai, Y., Hattori, S. and Tanimura, N., Relation between impact load and the damage produced by cavitation bubble collapse, Wear, 184 (1995), 231-239.

（7）岡田庸敬, 服部修次, キャビテーション壊食(8), 機械 の研究, 50-4 (1998), 79-85.

(8) Hattori, S., Mori, H. and Okada, T., Quantitative evaluation of cavitation erosion, Trans. ASME, J. of Fluids Eng., 120 (1998), 179-185.

(9) Hobbs, J.M., Experience with a $20-\mathrm{kc}$ cavitation erosion test, ASTM STP, 408 (1967), 159-185.

（10）岡田庸敬, 服部修次, 水島一寿, 渡辺靖久, 流れ環境中 の材料強度評価一キャビテーション壊食と材料の疲 労強度の関係, 日本機械学会材料力学部門講演会講演 論文集, B (1994), 395-396. 